\title{
Oncology teaching in undergraduate nursing at public institutions courses in Brazil
}

\author{
Ensino de oncologia nos cursos de graduação em Enfermagem de instituições públicas brasileiras \\ Enseñanza de oncología en los cursos de grado en Enfermería de instituciones públicas brasileñas
}

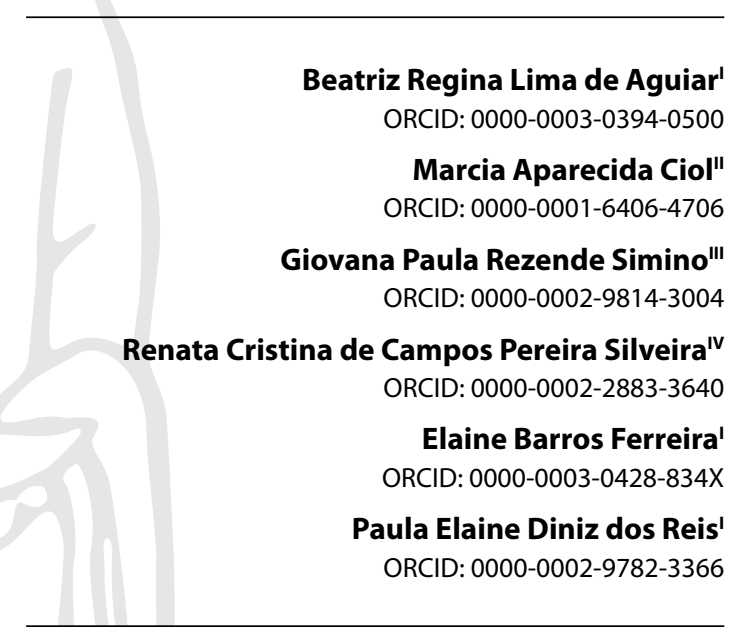

'Universidade de Brasília. Brasília, Distrito Federal, Brazil. "University of Washington. Seattle, Washington, Estados Unidos da América. '"Universidade Federal de Minas Gerais. Belo Horizonte, Minas Gerais, Brazil.

"Universidade de São Paulo. Ribeirão Preto, São Paulo, Brazil.

How to cite this article:

Aguiar BRL, Ciol MA, Simino GPR, Silveira RCCP, Ferreira EB, Reis PED. Oncology teaching in undergraduate nursing at public institutions courses in Brazil.

Rev Bras Enferm. 2021;74(2):e20200851. https://doi.org/10.1590/0034-7167-2020-0851

Corresponding author:

Beatriz Regina Lima de Aguiar E-mail: beatrizregina.rla@gmail.com

EDITOR IN CHIEF: Antonio José de Almeida Filho ASSOCIATE EDITOR: Álvaro Sousa

Submission: $07-24-2020$

Approval: $10-14-2020$

\section{ABSTRACT}

Objectives: to identify the occurrence of oncology teaching in undergraduate nursing curricula. Methods: descriptive study, which data was obtained from curriculum and from Pedagogical Course Projects available on the websites from Brazilian public institutions, between June and July 2020. Results: 143 undergraduate nursing courses were identified. From them, 132 nursing courses (corresponding to 89 education institutions) had available the curriculum and/or Pedagogical Course Projects. Only 7 (5.3\%) of them had oncology as a mandatory subject, 4 of them in the Midwest Region. Only 35 (26.5\%) had elective subject in Oncology, most of them in the Northeast (45.7\%). Conclusions: on third of nursing courses at public institutions has Oncology subject in the curriculum, which is few considering the high incidence and mortality from cancer in the country. The findings contribute for discussions, in curricular accommodation, on the relevance of oncology teaching in nursing curricula. Descriptors: Education, Nursing; Curriculum; Neoplasms; Education, Nursing, Diploma Programs; Education, Higher.

\section{RESUMO}

Objetivos: identificar a ocorrência de ensino de oncologia nos currículos de graduação em Enfermagem. Métodos: estudo descritivo, cujos dados foram obtidos da matriz curricular e do Projeto Pedagógico de Cursos disponíveis nos sites de instituições públicas brasileiras, entre junho e julho de 2020. Resultados: foram identificados 143 cursos de graduação em Enfermagem. Destes, 132 cursos de Enfermagem (correspondentes a 89 instituições de ensino) disponibilizavam a matriz curricular e/ou Projeto Pedagógico de Cursos. Apenas 7 (5,3\%) deles possuíam disciplina obrigatória de oncologia, sendo 4 na região Centro-Oeste. Somente 35 $(26,5 \%)$ disponibilizavam disciplina optativa em oncologia, a maioria no Nordeste $(45,7 \%)$. Conclusões: um terço dos cursos de Enfermagem de instituições públicas brasileiras tem o ensino de oncologia no currículo, o que é pouco considerando a alta incidência e mortalidade por câncer no país. Os achados contribuem para discussões, em reformas curriculares, sobre a relevância do ensino de oncologia nos currículos de Enfermagem.

Descritores: Educação em Enfermagem; Currículo; Neoplasia; Programas de Graduação em Enfermagem; Educação Superior.

\section{RESUMEN}

Objetivos: identificar ocurrencia de enseñanza de oncología en currículos de grado en Enfermería. Métodos: estudio descriptivo, datos obtenidos de la matriz curricular y de Proyecto Pedagógico de Cursos disponibles en el sitio de instituciones públicas brasileñas, entre junio y julio de 2020. Resultados: identificados 143 cursos de grado en Enfermería. De estos, 132 cursos de Enfermería (correspondientes a 89 instituciones de enseñanza) proveían la matriz curricular y/o Proyecto Pedagógico de Cursos. Solo 7 (5,3\%) de ellos poseían disciplina obligatoria de oncología, siendo 4 en el Centro-Oeste. Solamente $35(26,5 \%)$ proveían disciplina optativa en oncología, la mayoría en el Nordeste $(45,7 \%)$. Conclusiones: un tercio de los cursos de Enfermería de instituciones públicas brasileñas tienen enseñanza de oncología en el currículo, lo que es poco considerando la alta incidencia y mortalidad por cáncer en el país. Esto contribuye para discusiones, en reformas curriculares, sobre la relevancia de enseñanza de oncología en currículos de Enfermería.

Descriptores: Educación en Enfermería; Curriculum; Neoplasia; Programas de Graduación en Enfermería; Educación Superior. 


\section{INTRODUCTION}

The quality of care at distinct levels of health care is linked to the training of health professionals. In Brazil, the National Curricular Guidelines (DCNs) establish that the professional must be trained to act in clinic care, considering the epidemiological profile of the country ${ }^{(1)}$. The resolution 569, of December 8 , 2017 , sets out the general principles to be incorporated in the Curricular Guidelines of all undergraduate courses in the health area in Brazil and guides the development of the Pedagogical Course Project $(\mathrm{PCP})^{(1)}$.

Nursing is present in all types of health care and in all types of clinic specialties. Furthermore, it represents $50 \%$ of the contingent of workers of the area of health in ${ }^{(2)}$ and it is the category that works closer with health care patients. Therefore, the nurse training must be wide at the same time that the curricula and graduation PCPs should offer subsides in order the nurses can work with the main requirements of health of Brazilian population ${ }^{(3-4)}$. According to DCNs, the curricula must train the nurse for a generalist, humanist, critic, and reflexive education ${ }^{(4-5)}$. DCNs guide the elaboration of nursing PCP and, at the same time, allow the elaboration of curricula of each higher education institution (HEl) flexibly ${ }^{(6)}$. However, relaxing the elaboration of nursing curriculum allowed several curricular modifications with the time, and the minimum and mandatory curriculum model does not always cover all areas corresponding to the epidemiological situation of the population of $\mathrm{Brazi}^{(7-8)}$.

The prevalence of chronic diseases has been increased, and the epidemiological profile points cancer as the second leading cause of death in the world, behind only cardiovascular diseases ${ }^{(9)}$. The Globocan Project of World Health Organization estimated 9.6 million of death caused by cancer in the world and 18.1 million of new cases in $2018^{(10)}$, with the projection of 29.5 million of new cases in 2040(11). In Brazil, except for the non-melanoma skin cancer, the National Cancer Institute estimates for each of the triennial 2020-2022 625 thousand of new cases of cancer ${ }^{(12)}$. This panorama makes it increasingly frequent to assist cancer patients in all health services, including those that are not specialized ${ }^{(7,13-15)}$.

In Brazilian context, patients with cancer are frequently seen by generalist nurses, as the number of nurses specialized in oncology is still not sufficient to meet the demand ${ }^{(13,15-16)}$. Many times, nursing care is not accomplished as recommended by the guidelines because of the gap in the nurse knowledge regarding the particularities of the patient with cancer ${ }^{(13,17-18)}$. One of the reasons of this gap is the lack of subjects related to oncologic nursing in the curriculum of the nursing graduation courses ${ }^{(13,17-18)}$.

Although some studies based on interviews with nurses that work in the area describe that oncology teaching in nursing bachelor's courses are few ${ }^{(5,15,18-19)}$, there is still no study that quantifies the general panorama of oncology teaching in undergraduate nursing courses in Brazil. The analysis of nursing curricula is need in order to support discussions on the insertion of basic oncology teaching in the mandatory minimum.

\section{OBJECTIVES}

To identify the occurrence of oncology teaching in undergraduate nursing curricula.

\section{METHODS}

\section{Ethical aspects}

As it is a survey with public data source, there was waiver of the Informed Consent Form and appreciation by an Ethics in Research Committee. Teaching institutions were kept anonymous for analysis and presentation of data, but they can be found by directly search on the Education Ministry electronic system, the e-MEC, which accredits and regulates the higher education institutes in Brazil.

\section{Design, period and place of study}

The study is cross-sectional and descriptive, and its method was guided by the tool Strengthening the Reporting of Observational Studies in Epidemiology (STROBE), which offers guidelines for the design of observational studies. In this survey, the curricula of nursing courses from higher education institutes in Brazil were analyzed in order to quantify the presence of class hours of Oncology subjects in undergraduate nursing courses. Data was obtained from curriculum and from the Pedagogical Course Project, available on the higher education institutes websites of each nursing courses, which was searched between June 09 and July 02, 2020.

\section{Population; criteria of inclusion and exclusion}

The population considered was composed by all courses that graduated bachelor's degrees in nursing in public HEls, recognized and registered on the e-MEC system, which were active on the search date, and were offered as a classroom course. The intention was analyzing the curriculum of all courses, but some high education institutions were excluded because they did not inform the curriculum and/or PCP describing the offered subjects on the institution website.

\section{Study protocol}

First, a search on the e-MEC system website was performed in order to identify the public HEls in Brazil that offer nursing courses. To meet the eligibility criteria for these courses, the following filters were used: nursing course offered as a classroom course, nursing courses that offer bachelor's degree in nursing, active courses on the search date, and nursing courses offered in public $\mathrm{HEls}$. Within the study period, for each $\mathrm{HEl}$, the institution website was visited once for each search in order to find the curriculum and/or PCP of nursing undergraduate in each campus, since we may have more than one nursing course in the same HEl, with distinct curricula. Data collected was organized in an Excel table, including: characterization of the teaching institution (name the institution, city, State, Region, and administrative category), and the analysis of oncology teaching in the curriculum (presence of the Oncology subject, name of the Oncology subject, mandatory or elective options, as well as hours in classroom). Furthermore, the menus of other mandatory subjects were analyzed, including the search of themes that generally approach oncology, in one class at least, and the respective hours dedicated to such themes. 


\section{Analysis of results and statistics}

Data obtained was organized in Microsoft Excel and exported to the software SPSS - version 22. Statistical analysis was descriptive and included percentage of nursing courses with subjects on oncology, regional distribution, percentage of hours of the offered oncology subjects, and the frequency of oncology contents in other mandatory subjects of nursing curriculum.

\section{RESULTS}

On e-MEC system, 144 courses that graduate bachelor's degree in nursing at public higher graduation institutions were identified as classroom courses. After removing a duplicate institution that repeated its data on e-MEC system, 143 nursing courses remained. These belonged to 90 public HEls since there is more than one nursing course in many of the institutions. According to the eligibility criteria, 11 nursing courses were excluded because they did not provide curriculum or PCP on the institution website (9 from Northeast and 2 from Midwest). At the end, 132 nursing undergraduate courses were analyzed, offered in 89 Brazilian public HEls. Figure 1 describes the identification process of nursing undergraduate courses in public $\mathrm{HEl}$.

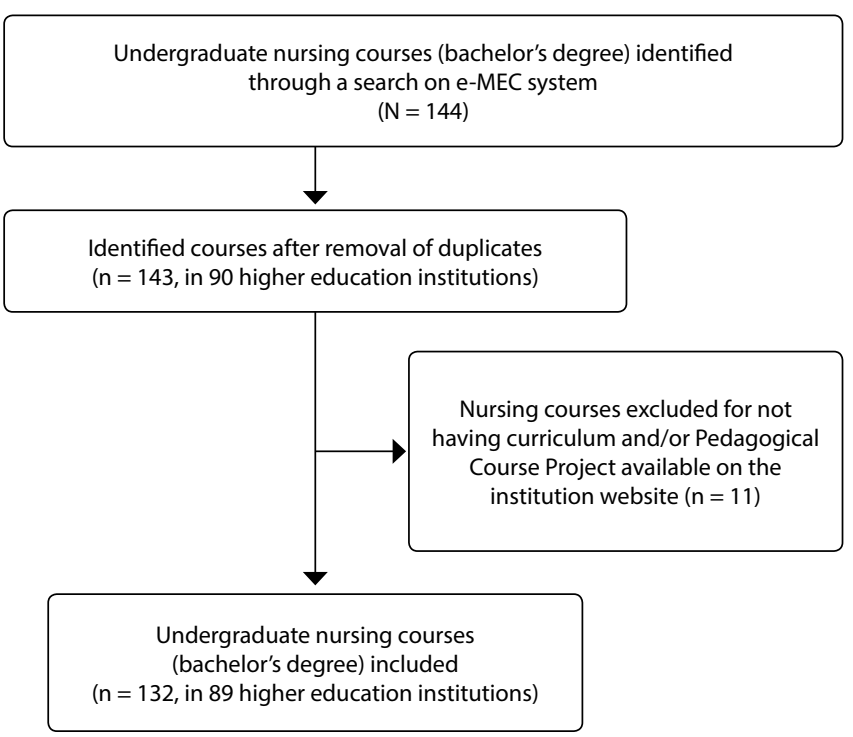

Note: HEI - Higher Education Institution.

Figure 1 - Flowchart of identification of undergraduate nursing courses in public higher education institutions registered on e-MEC system, Brazil, 2020

Table 1 shows the distribution of HEls according to the Region of the Country and the administrative nature (Federal, State or Municipal institution). Among the $89 \mathrm{HEls}$ included in the study, most corresponds to Federal level and to the Northeast and Southeast Regions. The number of HEls at the State level prevails in the Northeast Region. At Municipal level, we found a HEl in the Southeast Region.

Table 2 shows the number of nursing courses by Region in Brazil and the offer of mandatory and elective subjects on oncology in the curriculum. It is important to note that around one third (31.8\%) of nursing courses in public HEls in Brazil, considering the total of those institutions, have the oncology teaching inserted in curriculum as a mandatory or elective subject.

Table 3 shows the presence of Oncology Nursing subject, mandatory of elective in curriculum of nursing courses, per State. Most States do not have mandatory subject on Oncology Nursing, and many courses do not even offer it as an elective option.

Table 1 - Distribution of public higher education institution in Brazil, according to the Region and administrative nature, Brazil, 2020

\begin{tabular}{lcccc}
\hline & \multicolumn{4}{c}{ Public higher education institutions } \\
Region & $\begin{array}{c}\text { Administrative nature } \\
\text { Sederal }\end{array}$ & $\begin{array}{c}\text { State } \\
\mathbf{n}(\%)\end{array}$ & $\begin{array}{c}\text { Municipal } \\
\text { n (\%)* }\end{array}$ & $\begin{array}{c}\text { Total } \\
\mathbf{n}(\%)\end{array}$ \\
& $14(15.7)$ & $14(15.7)$ & $0(0.0)$ & $28(31.5)$ \\
Northeast & $14(15.7)$ & $8(9.0)$ & $1(1.1)$ & $23(25.8)$ \\
Southeast & $11(12.4)$ & $8(9.0)$ & $0(0.0)$ & $19(21.3)$ \\
South & $7(7.9)$ & $4(4.5)$ & $0(0.0)$ & $11(12.4)$ \\
North & $4(4.5)$ & $4(4.5)$ & $0(0.0)$ & $8(9.0)$ \\
Midwest & $50(56.2)$ & $38(42.7)$ & $1(1.1)$ & $89(100.0)$ \\
Total & & & & \\
\hline Note: ${ }^{*}$ Percentagecalculatedusing thetotalnumber ofhighereducationinstitutionsasareference $(n=89)$.
\end{tabular}

Table 2 - Distribution of nursing courses in public higher education institutions in Brazil and Oncology subject offer in the curriculum, Brazil, 2020

\begin{tabular}{|c|c|c|c|c|}
\hline \multirow{2}{*}{ Region } & \multirow{2}{*}{$\begin{array}{c}\text { Nursing } \\
\text { Courses } \\
n\end{array}$} & \multicolumn{2}{|c|}{$\begin{array}{c}\text { Subjects on Oncology } \\
\text { Nursing }\end{array}$} & \multirow{2}{*}{$\begin{array}{c}\text { Total } \\
\text { n }(\%)^{*}\end{array}$} \\
\hline & & $\begin{array}{c}\text { Mandatory } \\
\text { n (\%)* }\end{array}$ & $\begin{array}{l}\text { Elective } \\
\text { n }(\%)^{*}\end{array}$ & \\
\hline Northeast & 47 & $2(1.5)$ & $16(12.1)$ & 18 (13.6) \\
\hline Southeast & 29 & $1(0.7)$ & $8(6.1)$ & $9(6.8)$ \\
\hline South & 21 & $0(0.0)$ & $5(3.8)$ & $5(3.8)$ \\
\hline North & 18 & $0(0.0)$ & $1(0.7)$ & $1(0.7)$ \\
\hline Midwest & 17 & $4(3.0)$ & $5(3.8)$ & $9(6.8)$ \\
\hline Total & 132 & $7(5.3)$ & $35(26.5)$ & 42 (31.8) \\
\hline
\end{tabular}

Mandatory subjects are referred as "Oncology Nursing", "Nursing care in Oncology", or "Oncology and Palliative Care". Elective subjects are frequently referred as "Oncology Nursing". Some subjects encompass the prevention and control of cancer, nursing care in oncology palliative care, multiprofessional assistance in clinic oncology, nursing care in onco-hematology, and basic principles of oncology. Among the 7 nursing courses that offer mandatory subject in oncology, 5 have 30 hours per semester, and 2 have 45 hours. Among the 35 nursing courses that offer an elective oncology subject, 11 (31.4\%) have 30 hours per semester, 9 (25.7\%) have between 31 and 59 hours, 10 $(28.6 \%)$ have 60 hours, and $5(14,3 \%)$ have more than 60 hours. In nursing courses that have elective subjects on oncology, the greatest number of hours is offered in an institution from the Northeast ( 80 hours per semester). Midwest Region has the greatest number of hours of elective subjects in average (50.6 h; Standard Deviation:13.9).

Among the 132 nursing courses included, 107 showed the $P C P$, and $89(83.2 \%)$ of them had the oncology teaching included in the program content of the mandatory subjects of the nursing curriculum, having 26 in the Northeast, and 20 in the Southeast, 16 in the South, 15 in the Midwest, and 12 in the North. A campus often offers more than one mandatory subject with oncology 
content. Eighteen mandatory subjects were found having any oncology content on the menu of 89 nursing courses, and the percentage was calculated considering the 89 nursing courses that have oncology teaching included in the curriculum of other disciplines (Figure 2).

Although different contents that address oncology are included in the subjects' menu, few PCPs report the hours dedicated to this theme within the subjects, which makes it difficult to analyze the dissemination of knowledge in this area. Only 3 nursing courses, 2 in the Northeast Region and 1 in the Southeast Region, indicated the hours in PCP dedicated to oncology in other subjects of the curriculum, varying from 3 to 16 hours.

The North is the Region with the highest percentage of nursing courses that do not have an oncology subject in the curriculum, whether mandatory or elective, and that do not describe the study in oncology in the menu of other disciplines (27.8\%), followed the Northeast (23.4\%), the South (19.0\%), the Southeast (17.2\%) and the Midwest (11.8\%).

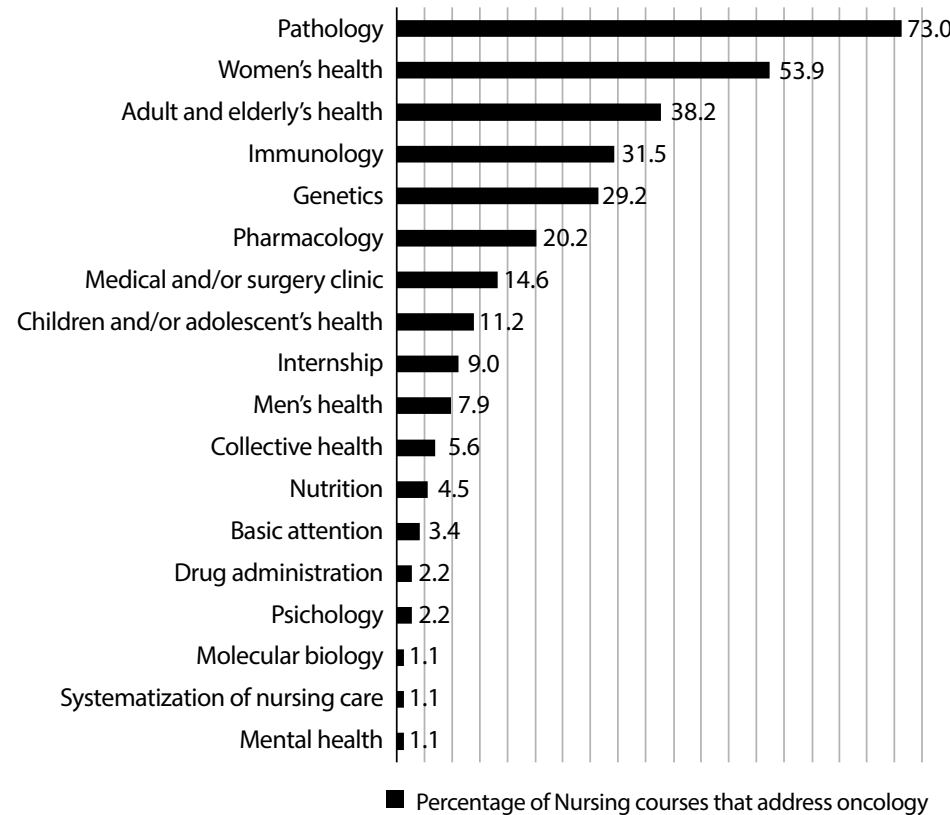

Figure 2 - Percentage of nursing courses that address oncology content in mandatory subjects in the curriculum $(n=89)$, Brazil, 2020
Table 3 - Distribution of nursing courses offered in public higher education institutions in Brazil per State and Oncology subject offered in curriculum, Brazil, 2020

\begin{tabular}{|c|c|c|c|}
\hline \multirow{2}{*}{ States by Region } & \multirow{2}{*}{$\begin{array}{c}\text { Nursing } \\
\text { Courses } \\
n\end{array}$} & \multicolumn{2}{|c|}{ Subjects on Oncology Nursing } \\
\hline & & $\begin{array}{c}\text { Mandatory } \\
\mathbf{n}^{*}\end{array}$ & $\begin{array}{c}\text { Elective } \\
\qquad \mathbf{n}^{* *}\end{array}$ \\
\hline \multicolumn{4}{|l|}{ Northeast } \\
\hline Paraíba & 5 & 2 & -- \\
\hline Bahia & 8 & -- & 5 \\
\hline Piauí & 7 & -- & 4 \\
\hline Ceará & 6 & -- & 3 \\
\hline $\begin{array}{l}\text { Rio Grande do } \\
\text { Norte }\end{array}$ & 5 & -- & 2 \\
\hline Maranhão & 4 & -- & 1 \\
\hline Alagoas & 3 & -- & 1 \\
\hline Pernambuco & 7 & -- & -- \\
\hline Sergipe & 2 & -- & -- \\
\hline \multicolumn{4}{|l|}{ Sudeste } \\
\hline Minas Gerais & 11 & 1 & 3 \\
\hline Rio de Janeiro & 6 & -- & 3 \\
\hline São Paulo & 10 & -- & 2 \\
\hline Espírito Santo & 2 & -- & -- \\
\hline \multicolumn{4}{|l|}{ Midwest } \\
\hline Goiás & 5 & 2 & 1 \\
\hline Mato Grosso & 5 & 2 & 1 \\
\hline Distrito Federal & 3 & -- & 2 \\
\hline Mato Grosso do & 4 & -- & 1 \\
\hline Sul & & & \\
\hline \multicolumn{4}{|l|}{ South } \\
\hline Paraná & 10 & -- & 3 \\
\hline Santa Catarina & 4 & -- & 2 \\
\hline Rio Grande do Sul & 7 & -- & -- \\
\hline \multicolumn{4}{|l|}{ North } \\
\hline Tocantins & 2 & -- & 1 \\
\hline Pará & 5 & -- & -- \\
\hline Amazonas & 4 & -- & -- \\
\hline Acre & 2 & -- & -- \\
\hline Amapá & 2 & -- & -- \\
\hline Roraima & 2 & -- & -- \\
\hline Rondônia & 1 & -- & -- \\
\hline
\end{tabular}

Note: * Nursing courses that offer mandatory oncology discipline; ${ }^{* *}$ Nursing courses that offer optional oncology discipline.

\section{DISCUSSION}

In this study, the analysis of the curricula of the courses in activity that graduate bachelors in Nursing from public HEls in Brazil allowed the identification that the frequency of teaching oncology in the curriculum of nursing courses is frequent in the Northeast Region, although the majority are from elective subjects. The Northeast is the Region with higher number of nursing courses, so we expected that the number of oncology subjects would also be greater in this Region. We know that there are still cities and municipalities in the Northeast of Brazil with difficult access to health care. For this reason, health professionals of this Region probably have minimum knowledge to assist patients with cancer and promote health education, trying to teach the population about risk factors, prevention, and early detection. Furthermore, the Northeast is the second Region in Brazil with the highest estimated incidence of cancer cases ${ }^{(12)}$, and curricular guidelines guide HEls to build the PCP based on the profile of the community that they will provide assistance ${ }^{(4)}$.

In the Southeast Region, from 29 existing nursing courses, only one has a mandatory subject on oncology in the curriculum, and 8 offer elective subjects. The South Region does not have nursing courses with mandatory subject on oncology and has only 5 elective subjects. Despite the Midwest have the lower number of nursing courses, is the Region with the largest number of mandatory oncology nursing subjects in the curriculum. The North presents elective oncology subject in only $0.7 \%$ of the nursing courses available in the Region.

Moraes et al. ${ }^{(20)}$ states that, in Brazil and in the world, there is a great concern with higher education due to the epidemiological profile of diseases, requiring, therefore, professional training that provides subsidies for professionals to work on the main health demands of the population. However, this study shows that oncology teaching in nursing curricula is present in only 
$31.8 \%$ of total of nursing courses offered in Brazil, a percentage that does not agree with the country's epidemiological reality. An example is the scares offer of oncology content in the Southeast and South Regions, which, according to INCA estimates, concentrate, respectively, $60 \%$ and $23.4 \%$ of new cancer cases per year, representing the first and third Regions with the highest incidence of cancer in the country ${ }^{(12)}$.

Oncology is often considered a specialized area, therefore the most part of HEls still does not have a specific subject on oncology in the curriculum ${ }^{(5,18)}$. Lins e Souza ${ }^{(5)}$ interviewed resident nurses in oncology trying to analyze barriers and facilitators in the process of education in this area. Only $14.3 \%$ of the interviewers reported having had an optional oncology course at graduation, and $76 \%$ stated that they did not feel prepared for the care of cancer patients due to lack of theoretical and practical classes during graduation, lack of experience, or lack of professional training ${ }^{(4)}$. It shows that oncology contents have been scarce in nursing undergraduate curricula for some time and that this fact may directly influence the care offered to cancer patients.

As it is a multidisciplinary area that applies to distinct stages of human development, oncology content can be taught in a fragmented way within the curriculum of general disciplines ${ }^{(16,21)}$. The analysis of the menus of other subjects in the curriculum of nursing courses found that some mandatory subjects have classes dedicated to the pathophysiology, control, prevention and diagnosis of cancer and/or assistance to cancer patients at different stages of human development. However, although there are themes offered related to oncology in the program content, the hours in the classroom may be considered very limited.

Fragmented teaching in undergraduate nursing courses was one of the principles of the first laws of guidelines and bases for higher education, but, over the years, it was modified by the restructuring of curricular guidelines ${ }^{(22)}$. However, teaching fragmentation in Brazil is still a challenge to be overcome ${ }^{(23)}$. Oncology content approached in general mandatory subjects, due to small number of hours presented, need to deepen concepts and particularities of care for cancer patients, which are essential for nursing care to this population. When planning the undergraduate nursing curriculum, it is essential that there is integration and coherence regarding the objective that the education of the graduated nurse allows him to act in the prevention, diagnosis, treatment, rehabilitation and palliative care according to the complexity of the levels in healthcare.

The training of generalist nurses has provided discussions regarding curricular plans that train professionals to act in the country's health situation $^{(24)}$. Souza, Cazola e Oliveira ${ }^{(25)}$ conducted a study to know the nurses' situation in the Family Health Strategy program that cares cancer patients in the city of Campo Grande, State of Minas Gerais. Results showed that $78 \%$ of the nurses interviewed had patients with cancer in their care area, and $95 \%$ of those nurses monitored cancer patients ${ }^{(25)}$. However, $45 \%$ of the interviewed nurses reported difficulties to provide care to cancer patients, mainly because of the lack of knowledge in oncology $(66 \%)$, and because of the lack of knowledge about the disease and its treatment $(46 \%)^{(25)}$.

Assistance to cancer patients at all levels of care requires specific knowledge to deal with the complexity of cases and to promote useful and appropriate interventions for patients and their families ${ }^{(13)}$. In this sense, it is necessary to reflect about the formal insertion of the oncology subject in nursing undergraduate curricula ${ }^{(5)}$.

Some strategies have been adopted in order to minimize this gap. One of them is the proposal of university extension programs (academic leagues), formed by undergraduate students who manage the league's activities under the supervision of a teacher linked to the HEls ${ }^{(26)}$. These activities are implemented according to the organization of each league, and their actions are based on the university tripod (teaching, research, and extension) aiming to complement the academic education in a specific area ${ }^{(26)}$. Other strategies under implementation are the research and extension projects that stimulate the education and the scientific production in oncology, aiming to reduce the gaps in academic and professional qualification in this area of knowledge ${ }^{(15,21,27)}$. Extension projects conducted in clinical practice contribute to the awareness of cancer prevention actions to be carried out with the community ${ }^{(15,21,27)}$. However, since both academic leagues and research and extension projects are considered extracurricular activities, the access is restricted only to those who have an interest or affinity with the area, in addition to having a number limited of places.

In Canada, nursing undergraduate curricula also lack oncology subjects that support the training of nurses, since newly graduated nurses, without previous experience in oncology, frequently work in places where they are responsible for the care of cancer patients ${ }^{(28)}$. In the United Kingdom, even if the Government recognizes the need to enhance nursing education and training in oncology, there are no specific guidelines regarding oncology teaching in nursing curricula(29). According to Koomprod ${ }^{(30)}$, there are no studies that describe how the oncology teaching is integrated to nursing curricula. However, the author emphasizes that the oncology teaching to nursing students is necessary to improve the knowledge and skills of future nurses.

Considering the current epidemiological situation of cancer in Brazil, which indicates a high incidence, and its projection for the coming decades, there is an urgent need to operationalize the insertion of minimum and mandatory program content in cancer care in the training of generalist nurses. This would enable nurses to act in health promotion in oncology, cancer control and prevention campaigns, early diagnosis, specific treatment, strategies for rehabilitation of cancer survivors and palliative care for terminal cancer patients. Therefore, it is necessary to encourage faculty from HEls to reflecting on the priorities in nursing education to act in clinical practice, including the need to insert subjects on oncology in the nursing undergraduate courses.

\section{Limitations of the study}

The study analysis was limited to the nursing courses that had curriculum and/or PCP on the teaching institutes websites, which did not allow working with the entire population of nursing courses present in public teaching institutes in Brazil. No attempt was made to request the curriculum in the teaching institutes of nursing courses that did not have such data on their website. 
Some of them restrict the exposition of the course hours and PCP, which made it impossible to analyze the oncology curriculum component included in the teaching plan for other mandatory subjects. As only 11 (7.7\%) of the curriculum could not be analyzed, our conclusions are still relevant in the face of the problem inside the public teaching institutions in Brazil. Private teaching institutions were not part of this study therefore, we suggest that new surveys are carried out including them.

\section{Contributions for the study for the area of nursing, health or public policies}

Morbidity and mortality profile of Brazilian population and the increase of incidence of cancer urge the need to graduate generalist nurses that understand the physiopathologic process of cancer and the specificities of assistance to cancer patients at all levels of health care. Our study discusses the importance of adding oncology subjects in nursing undergraduate courses and shows the need to this insertion so that professionals are able to offer specific care to cancer patients.

\section{CONCLUSIONS}

In this study, we identified that around one third of nursing courses of public teaching institutions in Brazil, considering their total, have the oncology teaching added in the curriculum as a mandatory or elective subject. In addition, when the subject is in the curriculum, elective or mandatory, the course hours are reduced when compared to the total in the curriculum of the nursing course. It is important that more nursing undergraduate courses include Oncology subject in the curriculum, as it will be necessary to assist patients with cancer at some point in professional practice, in a hospital specialized in oncology or in a general hospital, in view of the epidemiological profile of high incidence and mortality from the disease in Brazil.

We suggest that public entities responsible by the elaboration of curriculum guidelines: reinforce the importance and the need for curricula to offer subsidies, based on practical and theoretical content, so that nursing professionals are able to act on the main public health problems in Brazil; and stimulate public teaching institutions to add those contents in PCPs, during curricular modifications.

\section{REFERENCES}

1. Conselho Nacional de Saúde (Brasil). Resolução n 569, de 08 de dezembro de 2017 [Internet]. 2017 [cited 2020 May 28] Available from: https://conselho.saude.gov.br/resolucoes/2017/Reso569.pdf

2. Agência FioCruz de Notícias. Pesquisa inédita traça perfil da enfermagem no Brasil [Internet]. 2017 [cited 2020 Jul 03] Available from: https://agencia.fiocruz.br/pesquisa-in\%C3\%A9dita-tra\%C3\%A7a-perfil-da-enfermagem-no-brasil

3. Ximenes Neto FRG, Lopes Neto D, Cunha ICKO, Ribeiro MA, Freire NP, Kalinowski CE, et al. Reflexões sobre a formação em enfermagem no Brasil a partir da regulamentação do Sistema Único de Saúde. Ciênc Saúde Coletiva. 2020;25(1):37-46. https://doi. org/10.1590/1413-81232020251.27702019

4. Conselho Nacional de Educação (Brasil). Resolução CNE/CES no 3, de 7 de novembro de 2001. Institui Diretrizes Curriculares Nacionais do Curso de Graduação em Enfermagem [Internet]. Diário Oficial da União: República Federativa do Brasil; 2001 [cited 2020 May 22]. Nov 9, Seção1: [about 6 screens]. Available from: http://portal.mec.gov.br/cne/arquivos/pdf/CES03.pdf

5. Lins FG, Souza SR. Formação dos enfermeiros para o cuidado em oncologia. Rev Enferm UFPE. 2018;12(1):66-74. https://doi. org/10.5205/1981-8963-v12i01a22652p66-74-2018

6. Frota MA, Wermelinger MCMW, Vieira LJES, Ximenes Neto FRG, Queiroz RSM, Amorim RF. Mapeando a formação do enfermeiro no Brasil: desafios para atuação em cenários complexos e globalizados. Ciênc Saúde Coletiva. 2020;25(1):25-35. https://doi. org/10.1590/1413-81232020251.27672019

7. Calil AM, Prado C. Ensino de oncologia na formação do enfermeiro. Rev Bras Enferm. 2010;63(4):671-4. https://doi.org/10.1590/ S0034-71672010000400026

8. Rodrigues J, Kempfer SS, Lenz JR, Oliveira SN. Influência das reformas curriculares no ensino de saúde mental em enfermagem: 1969 a 2014. Rev Gaúcha Enferm. 2017;38(3):e67850. https://doi.org/10.1590/1983-1447.2017.03.67850

9. GBD 2015. Mortality and Causes of Death Collaborators. Global, regional, and national life expectancy, all-cause mortality, and causespecific mortality for 249 causes of death, 1980-2015: a systematic analysis for the Global Burden of Disease Study 2015. Lancet. 2016;388:1459-544. https://doi.org/10.1016/S0140-6736(16)31012-1

10. Bray F, Ferlay J, Soerjomataram I, Siegel RL, Torre LA, Jemal A. Global Cancer Statistics 2018: GLOBOCAN Estimates of Incidence and Mortality Worldwide for 36 Cancers in 185 Countries. CA: Cancer J Clin. 2018;68:394-424. https://doi.org/10.3322/caac.21492

11. International Agency for Research in Cancer, World Health Organization [Internet]. Cancer Tomorrow. 2019 [cited 2020 May 18]. Available from: https://gco.iarc.fr/tomorrow/home

12. Instituto Nacional de Câncer José Alencar Gomes da Silva. Coordenação de Prevenção e Vigilância. Estimativa 2020: incidência de câncer no Brasil [Internet]. Rio de Janeiro: INCA, 2019[cited 2020 Feb 19]. 130 p. Available from: https://www.inca.gov.br/publicacoes/livros/ estimativa-2020-incidencia-de-cancer-no-brasil

13. Peiter CC, Caminha MEP, Lanzoni GMM, Erdmann AL. Gestão do cuidado de enfermagem ao paciente oncológico num hospital geral: uma Teoria Fundamentada nos Dados. Rev Enferm Ref. 2016;11:61-9. https://doi.org/10.12707/RIV16044 
14. Gonçalves MM, Guedes NAB, Matos SS, Tiensoli SD, Simino GPR, Corrêa AR. Perfil dos atendimentos a pacientes oncológicos em uma unidade de pronto atendimento. Rev Enferm Cent Oeste Min. 2018;8:e2595. https://doi.org/10.19175/recom.v7i0.2595

15. Rosa LM, Andrade AE, Berndt LK, Anders JC, Radunz V, Souza AIJ. Atenção oncológica na atenção básica: projeto de extensão na formação de acadêmicos de enfermagem. Rev Eletron Extensão. 2017; 14(26):107-18. https://doi.org/10.5007/1807-0221.2017v14n26p107

16. Magnago C, Pierantoni CR. A formação de enfermeiros e sua aproximação com os pressupostos das Diretrizes Curriculares Nacionais e da Atenção Básica. Ciênc Saúde Coletiva. 2020; 25(1):15-24. https://doi.org/10.1590/1413-81232020251.28372019

17. Luz KR, Vargas MAO, Rosa LM, Schmitt PH. Enfermeiros na atenção oncológica: conhecimento na prática do cuidado. Rev Enferm UFPE. 2016;10(9):3369-76. https://doi.org/10.5205/reuol.9571-83638-1-SM1009201623

18. Rosa LM, Souza AIJ, Anders JC, Silva RN, Silva GS, Fontão MC. Demandas de atendimento de enfermagem e de qualificação em oncologia na atenção básica em saúde. Cogitare Enferm. 2017;(22)4:e51607. https://doi.org/10.5380/ce.v22i4.51607

19. Ferreira DS, Bernardo FMS, Costa EC, Maciel NS, Costa RL, Carvalho CML. Conhecimento, atitude e prática de enfermeiros na detecção do câncer de mama. Esc Anna Nery. 2020;24(2):e20190054. https://doi.org/10.1590/2177-9465-EAN-2019-0054

20. Moraes A, Guariente MHDM, Garanhani ML, Carvalho BG. A formação do enfermeiro em pesquisa na graduação: percepções docentes. Rev Bras Enferm. 2018;71(suppl4):1648-56. https://doi.org/10.1590/0034-7167-2017-0511

21. Ferreira DAV, Silva AP, Silva KRX. Ensino de oncologia na graduação médica e autorregulação da aprendizagem. Rev HUPE. 2015;14(1):50-8. https://doi.org/10.12957/rhupe.2015.17774

22. Ferreira RGS, Nascimento JL. Sustentação pedagógica e legislação do ensino-aprendizagem: a formação em enfermagem no Brasil. Rev Sustinere. 2017;5(1):54-67. https://doi.org/10.12957/sustinere.2017.25551

23. Batista NA, Rossit RAS, Batista SHSS, Silva CCB, Uchôa-Figueiredo LR, Poletto PR. Educação interprofissional na formação em saúde: a experiência da Universidade Federal de São Paulo, campus Baixada Santista, Santos, Brasil. Interface. 2018;22(supl.2):1705-15. https://doi. org/10.1590/1807-57622017.0693

24. Padovani O, Corrêa AK. Currículo e formação do enfermeiro: desafios das universidades na atualidade. Saude Transf Soc [Internet]. 2017 [cited 2020 May 28];8(2):112-9. Available from: http://incubadora.periodicos.ufsc.br/index.php/saudeetransformacao/article/ view/3841/4990

25. Souza GRM, Cazola LHO, Oliveira SMVL. Atuação dos enfermeiros da estratégia saúde da família na atenção oncológica. Esc Anna Nery. 2017; 21(4):e20160380. https://doi.org/10.1590/2177-9465-ean-2016-0380

26. Souzai LS, Noguchii CS, Alvaresi LB. Uma nova possibilidade de construção do conhecimento em psicologia. Estud Interdisc Psicol. 2019;10(1):237-51. https://doi.org/10.5433/2236-6407.2019v10n1p237

27. Faria ET, Vieira LAC, Matsuura LC. Liga de Combate ao Câncer da Universidade de Brasília. In: Santos M, Corrêa TS, Faria LDBB. Diretrizes Oncológicas. 2 Ed. São Paulo: Doctor Press Ed Cientifica; 2019. p. 835-43.

28. Mitchell C, Laing CM. Revision of an undergraduate nursing oncology course using the Taylor Curriculum reviews process. Can Oncol Nurs J. 2019;29(1):47-51. https://doi.org/10.5737\%2F236880762914751

29. O'Connor SJ, Fitzsimmons D. Embedding cancer care within pre-registration nurse education programmes: policy, practice and opportunities for change. Eur J Oncol Nurs. 2005;9(4):341-50. https://doi.org/10.1016/j.ejon.2005.02.002

30. Komprood SR. Nursing student attitudes toward oncology nursing: an evidence-based literature review. Clin J Oncol Nurs. 2013;17(1):E21-8. https://doi.org/10.1188/13.cjon.e21-e28 